\title{
Interaction of bovine granulosa and theca cells in a novel serum-free co-culture system
}

\author{
C. Allegrucci ${ }^{1}$, M. G. Hunter ${ }^{1}$, R. Webb ${ }^{2}$ and M. R. Luck ${ }^{1 *}$ \\ ${ }^{1}$ Division of Animal Physiology, and ${ }^{2}$ Division of Agricultural Sciences, School of Biosciences, \\ University of Nottingham, Sutton Bonington, Loughborough LE12 5RD, UK
}

\begin{abstract}
The objective of this study was to develop a defined culture system in which bovine follicular and granulosa cells are grown in close contact with each other and with the extracellular matrix (ECM) component laminin. Granulosa and theca cells from follicles 4-6 $\mathrm{mm}$ in diameter were cultured on either side of laminin-coated BioCoat ${ }^{\mathrm{TM}}$ cell culture inserts in a serum-free medium containing $10 \mathrm{ng}$ insulin $\mathrm{ml}^{-1}$ at plating densities of $10^{5}$ and $3 \times 10^{5}$ cells per membrane side. The cells adopted a clumped arrangement, maintained steroidogenic activity for at least 7 days and demonstrated paracrine communication by increased steroidogenesis and enhanced cell survival compared with cells in mono-culture. Co-cultured theca cells secreted significantly more androstenedione compared with cells in mono-culture. Granulosa cell viability was doubled by
\end{abstract}

co-culture with theca cells. Co-cultures at both cell plating densities were responsive to treatment with physiological combinations of either FSH, LH and LR3 insulin-like growth factor I (IGF-I) (treatment A) or FSH, LR3 IGF-I and androstenedione (treatment B). Significantly more androstenedione was secreted in the presence of treatment A compared with controls. In contrast, oestradiol secretion was increased only by treatment B. Progesterone secretion was unaffected by treatment and did not increase during culture. Co-cultures at the higher plating density demonstrated higher theca cell survival and better maintenance of the follicular cell phenotype. In conclusion, this novel co-culture system provides a unique model for the study of paracrine communication between ovarian somatic cells and cell-ECM interactions during follicle growth.

\section{Introduction}

Follicle development is a dynamic process controlled by a complex of extraovarian signals, including gonadotrophins, and locally produced ovarian hormones and growth factors.

During follicle growth, marked proliferation and differentiation of the follicular somatic cells takes place. These events are finely regulated by locally acting factors with both autocrine and paracrine actions. However, little is known about how granulosa and theca cells communicate on either side of the follicular basal lamina, particularly during the crucial expansion phases of follicle development (Webb et al., 1999). The basal lamina creates a permeable barrier between the two follicular cell compartments and the presence of this extracellular matrix (ECM) boundary influences the interactions of follicular somatic cells (Luck, 1994; Rodgers et al., 2000). Communication between granulosa and theca cells is exerted at the hormonal level. Indeed, coordination of cellular activity is required for hormone biosynthesis under gonadotrophic control (Webb et al., 1999). Theca cells synthesize androgens, which are

${ }^{*}$ Correspondence

Email: martin.luck@nottingham.ac.uk the substrate for aromatization and act as paracrine hormones to control steroidogenesis induced by FSH in granulosa cells (Gore-Langton and Armstrong, 1994; Webb et al., 1999). Oestradiol is also known to stimulate thecal production of androstenedione and decrease progesterone synthesis (Roberts and Skinner, 1990). Intraovarian regulators, such as cytokines and growth factors, mediate the effects of gonadotrophins in regulating granulosa-theca cell interactions. Communication between bovine granulosa and theca cells is mediated in part by a range of factors, including kit ligand, keratinocyte growth factor (KGF), hepatocyte growth factor (HGF), transforming growth factor $\beta$ (TGF- $\beta$ ), epidermal growth factors (EGF and TGF- $\alpha$ ), fibroblast growth factor, insulin-like growth factors I and II (IGF-I and -II), activin, inhibin and follistatin (Monniaux et al., 1997; Webb et al., 1999; Knight and Glister, 2001; Nilsson and Skinner, 2001). However, increasing evidence indicates that the interaction between granulosa and theca cells depends not only on paracrine communication, but also on their contact with the basal lamina (Luck, 1994; Rodgers et al., 2000; Rodgers and IrvingRodgers, 2002). Basement membrane and associated ECM components have different functions in many tissues, including control of cell anchorage, migration, division, differentiation and death (Adams and Watt, 1993; 
Streuli, 1999). The ECM can also interact with growth factors in a variety of ways to regulate cell behaviour. The ECM not only provides binding sites for growth factors, but also participates in the mechanism of reciprocal regulation, which is responsible for gene expression of ECM proteins and their receptors, and of expression of growth factors and their receptors (Adams and Watt, 1993; Streuli, 1999). Recent evidence supports the involvement of ECM components in regulating granulosa cell survival, proliferation and steroidogenesis in the ovarian follicles of several species (Aharoni et al., 1997; Huet et al., 2001; Le Bellego et al., 2002). A continuous remodelling of the basal lamina occurs during follicle development and its composition is altered during this process (Luck, 1994; Rodgers et al., 2000).

Theca and granulosa cells need to be cultured under serum-free conditions, in close proximity to each other and to ECM components to reproduce the in vivo environment of the follicle. Serum-free conditions are a crucial requirement because, although the addition of serum provides a complex mixture of hormones, growth and adhesion factors required for cell proliferation, it is impossible to control or know the identity of all the constituents of serum that affect cell function and differentiation. In addition, use of serum can apparently result in the luteinization of granulosa and theca cells (Gong et al., 1994; Wrathall and Knight, 1995), as characterized by a decrease in oestradiol and androstenedione production and by a rapid and sustained increase in progesterone synthesis. Improved serum-free culture methods have been developed for granulosa (Campbell et al., 1996; Gutierrez et al., 1997; Picton et al., 1999) and theca cells (Campbell et al., 1998; Shores et al., 2000), but these models use granulosa and theca cells in separate cultures or in mixed cultures without separation by an ECM-coated membrane. In a co-culture system, bovine granulosa and theca cells have been placed on opposite sides of a collagen type I membrane (Yada et al., 1999; Tajima et al., 2002). This system involved preliminary culture with serum and exposed the cells to high concentrations of insulin.

The aim of the present study was to develop an entirely serum-free co-culture of follicular somatic cells, which would resemble, as closely as possible, the in vivo conditions of follicle development, particularly with respect to ECM exposure and hormonal support. Although collagen type I participates in the maintenance of normal hormone secretion by granulosa cells, laminin is known to sustain follicle development by enhancing cell survival and proliferation (Huet et al., 2001). Therefore, in the present study cultured granulosa and theca cells were cultured on opposite sides of a laminin-coated, porous membrane. This arrangement provides adjacent but separated cellular compartments with a contiguous fluid phase, which can be used to investigate cellular interactions. The use of defined media has allowed us to study the effects of physiological doses of IGF-I, insulin and gonadotrophins and establish conditions under which co-cultured cells maintain their follicular phenotype.

\section{Materials and Methods}

\section{Materials}

Dulbecco's modified Eagle's medium and nutrient mixture F-12 Ham (DMEM-F12), and penicillinstreptomycin-glutamine were from Gibco-Invitrogen Corporation (Paisley, Renfrewshire). Falcon BD BioCoat $^{\mathrm{TM}}$ cell culture inserts, mouse laminin (from Engelbreth-Holm-Swarm mouse tumour) were from BD Biosciences (Cowley, Oxford). Ovine FSH (NIDDKoFSH-19-SIAPP, bioactivity $94 \mathrm{~S} 1$ units $\mathrm{mg}^{-1}$ ) was generously donated by National Institute of Diabetes and Digestive and Kidney Diseases (Torrance, CA). Bovine LH (USDA-bLH-B6-AFP11743B, bioactivity $2.3 \mathrm{~S} 1$ units $\mathrm{mg}^{-1}$ ) was generously donated by US Department of Agriculture (Beltsville, MD). ELISA kits for progesterone analysis were purchased from Ridgeway Science Ltd (Alvington, Gloucestershire). All other chemicals and reagents were purchased from SigmaAldrich Company Ltd (Poole, Dorset).

\section{Isolation of theca and granulosa cells}

Bovine ovaries, obtained from an abattoir at random stages of the oestrous cycle, were transported at ambient temperature in isotonic solution. After several washes in isotonic solution, selected ovaries were rinsed briefly in $70 \%(\mathrm{v} / \mathrm{v})$ ethanol and then transferred into collection medium (DMEM-F12 medium containing $100.0 \mathrm{U}$ penicillin $\mathrm{ml}^{-1}, 100.0 \mu \mathrm{g}$ streptomycin $\mathrm{ml}^{-1}$, $2.5 \mu \mathrm{g}$ amphotericin $\mathrm{B} \mathrm{ml}^{-1}$ ). The stage of the oestrous cycle was determined morphologically, as described by Ireland et al. (1980). Healthy developing follicles were assessed according to Metcalf (1982) for a vascularized pink theca externa and amber follicular fluid without debris. Medium-sized follicles (4-6 mm in diameter) were selected and follicular fluid was aspirated using a syringe with a 19-gauge needle. Follicles were opened by making a small incision on the surface and the interior was washed with a few drops of collection medium to remove residual follicular fluid and cell debris. Mural granulosa cells were removed by gentle scraping of the follicle wall with a plastic inoculation loop and collected by aspiration. The theca cell layers were peeled away from the follicle and observed under a dissection microscope to check for the complete removal of granulosa cells. Chopped theca layers were digested by incubation with $1 \mathrm{mg}$ collagenase $\mathrm{ml}^{-1}, 1 \mathrm{mg}$ hyaluronidase $\mathrm{ml}^{-1}$ and $1 \mathrm{mg}$ dispase $\mathrm{ml}^{-1}$ in $\mathrm{PBS}\left(\mathrm{Mg}^{2+}-\mathrm{Ca}^{2+}\right.$ free) for $1 \mathrm{~h}$ at $37^{\circ} \mathrm{C}$ (Campbell et al., 1998). After $20 \mathrm{~min}$ of digestion, $100 \mu \mathrm{g}$ DNase $\mathrm{I} \mathrm{ml}^{-1}$ was added to the digestion mixture. Dispersed granulosa and theca cells 


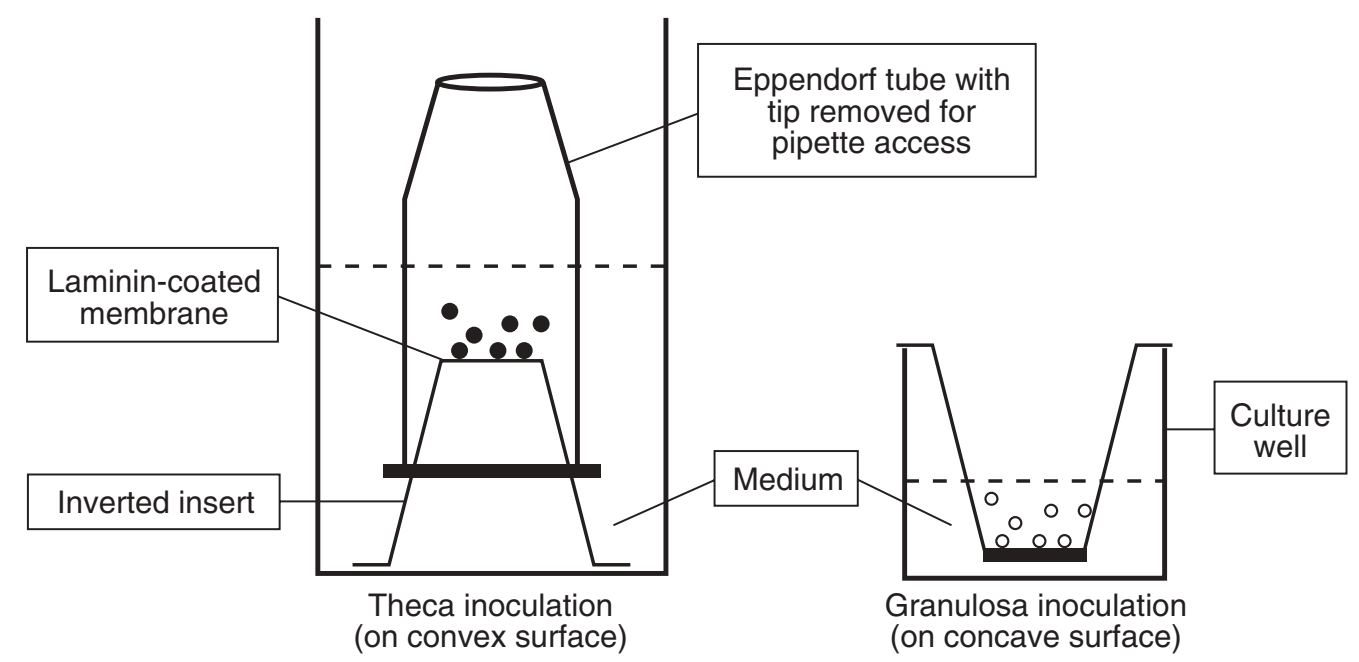

Fig. 1. Method of achieving co-culture of bovine theca (outer surface) and granulosa (inner surface) cells on the laminin-coated membrane of the cell culture insert. Theca inoculation on the inverted insert took place in a deep container allowing at least $5 \mathrm{~mm}$ depth of medium above the membrane surface. Attachment of theca cells was allowed to proceed overnight before reversion of the insert and transfer to a culture plate well for granulosa inoculation.

were centrifuged separately at $800 \boldsymbol{g}$ for $10 \mathrm{~min}$ and the pellets resuspended in $100 \mu \mathrm{l}$ of red blood cell lysis buffer $\left(8.3 \mathrm{mg} \mathrm{NH}_{4} \mathrm{Cl} \mathrm{ml}^{-1}\right.$ in $10.0 \mathrm{mmol}$ Tris-HCl I-1 buffer) and incubated for 1 min. Isotonicity was restored by addition of $10 \mathrm{ml}$ of collection medium and cells were then washed twice in collection medium by centrifugation at $800 \mathrm{~g}$ for $10 \mathrm{~min}$. Granulosa and theca cells were resuspended in culture medium (DMEM-F12 medium containing $100.0 \mathrm{U}$ penicillin $\mathrm{ml}^{-1}, 100.0 \mu \mathrm{g}$ streptomycin $\mathrm{ml}^{-1}, 2.0 \mathrm{mmol}$ glutamine $\mathrm{I}^{-1}, 10.0 \mathrm{ng}$ insulin $\mathrm{ml}^{-1}, 2.5 \mu \mathrm{g}$ apotransferrin $\mathrm{ml}^{-1}, 4.0 \mathrm{ng}$ sodium selenite $\mathrm{ml}^{-1}$ and $1.0 \mathrm{mg} \mathrm{BSA} \mathrm{ml}^{-1}$ ) and counted using a haemocytometer. Cell viability, estimated by Trypan blue dye exclusion, was $20-30 \%$ and $80-90 \%$ for granulosa and theca cells, respectively.

\section{Coating of cell culture inserts with laminin}

Both sides of the Falcon BD BioCoat ${ }^{\mathrm{TM}}$ control cell culture inserts (24-well plates, $3 \mu \mathrm{m}$ pores) were coated with $5 \mu \mathrm{g}$ laminin $\mathrm{cm}^{2}$ by soaking the inserts in a 24-well plate (solution DMEM-F12 medium). After $1 \mathrm{~h}$ of incubation at room temperature, the coating was allowed to air dry. Inserts were stored for up to 2 weeks at $4^{\circ} \mathrm{C}$ and then hydrated in culture medium for $30 \mathrm{~min}$ at $37^{\circ} \mathrm{C}$ before use.

\section{Granulosa and theca cell co-culture}

An inoculation chamber was created by positioning an Eppendorf $1.5 \mathrm{ml}$ tube, previously opened by removing the cap and the rounded part of the tip, on the top of an upturned cell culture insert (Fig. 1). Viable theca cells $\left(10^{5}\right.$ in $500 \mu$ l of culture medium) were inoculated in the chamber thus formed and allowed to attach overnight to the outer (convex) surface of the insert membrane. The insert was immersed in medium to a depth of about $5 \mathrm{~mm}$ above the level of the membrane during this time. The next day, the chamber was removed and the reverted insert fitted into a 24-well BD Falcon cell culture inserts companion plate, equilibrated with $500 \mu \mathrm{l}$ of culture medium. Freshly prepared granulosa cells $\left(10^{5}\right.$ viable cells in $500 \mu \mathrm{l}$ of culture medium) were inoculated to the inside (concave) surface of the insert to obtain the coculture arrangement (Fig. 1). The opposite arrangement, in which granulosa cells were first allowed to attach to the outer surface and then theca cells inoculated to the inner surface, was tested during optimization and was found to result in lower attachment rates. Granulosa and theca mono-cultures, used for comparison with co-cultures, were created using the procedures described above but omitting one of the types of cell. The effect of plating density on cellular activity was tested by comparing cultures with inoculations of $10^{5}$ and $3 \times 10^{5}$ viable theca and granulosa cells. Cultures were maintained for 7 days at $37^{\circ} \mathrm{C}, 5 \% \mathrm{CO}_{2}$ and $95 \%$ humidity. Sixty-five per cent of the total medium in each well $(650 \mu \mathrm{l}$ of $1 \mathrm{ml})$ was changed every day. Spent media were stored at $-20^{\circ} \mathrm{C}$ until used for hormone measurement.

\section{Co-culture treatments}

The effects of FSH $\left(0.3 \mathrm{ng} \mathrm{ml}^{-1}\right)$, $\mathrm{LH}\left(0.1 \mathrm{ng} \mathrm{ml}^{-1}\right)$, LR3 IGF-I $\left(1 \mathrm{ng} \mathrm{ml}^{-1}\right)$ and androstenedione $\left(10^{-7} \mathrm{~mol}\right.$ $\mathrm{I}^{-1}$ ) were tested on co-cultures (plating densities of $10^{5}$ and $3 \times 10^{5}$ cells) in the following combinations: (i) LR3 IGF-I, FSH and LH (treatment A) and (ii) LR3 IGF-I, $\mathrm{FSH}$ and androstenedione (treatment $\mathrm{B}$ ). Treatments were 
added from the start of culture and at each change of medium.

\section{Hormone measurement}

Concentrations of oestradiol and androstenedione in unextracted culture medium from mono-cultures and cocultures were measured by radioimmunoassay (Gutierrez et al., 1997; Campbell et al., 1998). Oestradiol assay sensitivity was $0.6 \mathrm{pg} \mathrm{ml}^{-1}$ and the inter- and intra-assay coefficients of variation were 9.4 and $7.5 \%$, respectively. Androstenedione assay sensitivity was $8 \mathrm{pg} \mathrm{ml}^{-1}$ and the inter- and intra-assay coefficients of variation were 11.1 and $6.9 \%$, respectively. Progesterone concentrations were determined by ELISA that was validated for culture medium (Picton et al., 1999). Assay sensitivity was $0.5 \mathrm{ng} \mathrm{ml}^{-1}$ and the inter- and intra-assay coefficients of variation were 13.7 and $8.8 \%$, respectively.

\section{Determination of the number of viable cells}

At the end of the culture period, the number of theca and granulosa cells was estimated by the cellular conversion of methyltriazole tetrazolium (MTT) (Mosmann, 1983). Theca and granulosa cells were detached from the insert membrane by treatment with $0.25 \%(\mathrm{w} / \mathrm{v})$ trypsinEDTA for 2 min at $37^{\circ} \mathrm{C}$. After trypsin deactivation by the addition of fetal calf serum, cells were collected separately from the insert and centrifuged at $800 \mathrm{~g}$ for $10 \mathrm{~min}$. The cells were then washed twice in DMEM-F12 medium (BSA- and phenol red-free) containing $10 \mathrm{mmol}$ Hepes $\mathrm{I}^{-1}$ and resuspended in $100 \mu \mathrm{l}$ of the same medium. Cell suspensions were transferred to a 96-well plate and incubated with $10 \mu \mathrm{l}$ of a MTT stock solution $\left(5 \mathrm{mg} \mathrm{ml}^{-1}\right)$ for $4 \mathrm{~h}$ at $37^{\circ} \mathrm{C}$. At the end of the incubation period, $100 \mu \mathrm{l}$ of a MTT solubilization solution (consisting of $10 \%(\mathrm{v} / \mathrm{v})$ Triton-X100, $0.1 \mathrm{~N}$ $\mathrm{HCl}$ in anhydrous isopropanol) was added to the wells to dissolve the formazan crystals. The resulting purple solution was measured using a spectrophotometer at $570 \mathrm{~nm}$. The relationship between absorbance and the number of cells was determined by previously incubating known quantities of cells with MTT and creating a standard curve. The curve was linear over a range of $10^{3}$ to $10^{6}$ cells with a lower detection limit of $10^{3}$ cells.

\section{Statistical analyses}

Data from time course experiments are presented as mean daily hormone concentration after correction for the residual amount of medium remaining in the wells during the medium change. Data are also expressed for the last day of culture as concentration of hormone per 20000 viable cells measured at that time. The results presented in the present study are based on at least three independent cultures, each culture using wells and inserts in triplicate. The data were $\left(\log _{10}+1\right)$ transformed to remove heterogeneity of variance before analysis.
Statistical analysis was performed by repeated measures of ANOVA using GenStat for Windows, 6th edition. Replicate cultures were treated as block structures; $P$ values are shown for the overall analysis. The pooled variance was used to calculate the standard error of the difference (SED) between two means. Effects were considered significant at $P<0.05$.

For the viable cell number determinations, data are presented as means $\pm \operatorname{SEM}(n \geqslant 3)$. Statistical comparison of means was by ANOVA and, when indicated, by Tukey-Kramer post hoc test. The results were considered significantly different at $P<0.05$.

\section{Results}

\section{Granulosa and theca co-culture optimization}

After coating, laminin formed a thin polymer (described by Yurchenco et al., 1985, 1992) on both sides of the cell culture insert membrane, thus allowing both types of cell to interact with the ECM component. Theca cells showed better attachment compared with granulosa cells (approximately 80 and $10 \%$, respectively; data not shown) after the overnight incubation and inversion of the insert. For this reason, theca cells were always seeded first during the co-culture procedures. Theca cell attachment was further improved by the physical removal of contaminating red blood cells using ammonium chloride treatment (data not shown).

\section{Cell morphology and cell number}

After overnight incubation, theca cells formed a network of well-attached cell clusters, which evolved into dense cell clumps by the end of the first day of culture. Some fibroblast-like cells with projections were also observed by the second day of culture, both at the base and between theca cell clumps. In contrast, granulosa cells started to form clumps by the second day of culture. After 4 days of culture, some elongated cells were visible at the base of the granulosa cell clumps and projections towards other clumps could be observed. No obvious difference in cell morphology was observed between mono- and co-cultures for either type of cell. Granulosa and theca cell morphology in co-culture, plated at a density of $10^{5}$ cells per insert, is shown (Fig. 2a,b). The size and the shape of the clumps were dependent on the cell plating density; the clumps were bigger and more inter-connected at the higher cell plating density. Cells in co-culture were also distributed more evenly on the cell culture insert membrane at the higher cell plating density (Fig. 2c,d). No changes in cell morphology were observed with either treatment A (LR3 IGF-I, FSH and LH) or treatment B (LR3 IGF-I, FSH and androstenedione). After 7 days of culture, under basal conditions (10 ng insulin $\mathrm{ml}^{-1}$ ) at a plating density of $10^{5}$ cells per insert, the number of theca and granulosa cells recovered from the mono-cultures was approximately $20 \%$ of 

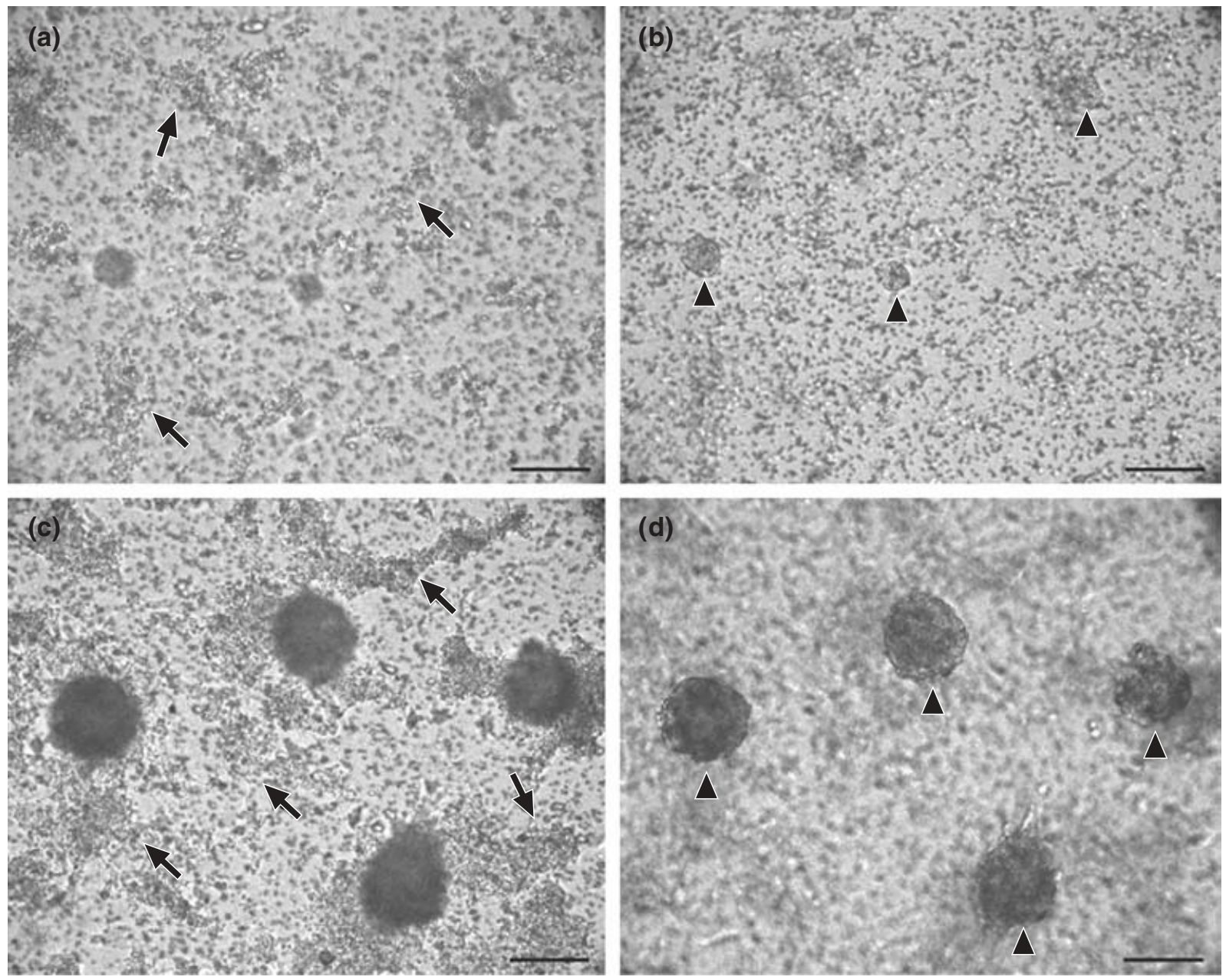

Fig. 2. Morphology of bovine granulosa and theca cells in co-culture. Cells were co-cultured for 7 days under basal conditions $\left(10 \mathrm{ng}\right.$ insulin $\mathrm{ml}^{-1}$ ) at a density of either $(\mathrm{a}, \mathrm{b}) 10^{5}$ or $(\mathrm{c}, \mathrm{d}) 3 \times 10^{5}$ of each type of cell per cell culture insert. Cells were observed using an inverted microscope fitted with a long distance objective. Representative images, corresponding to the same observation field but in different focal planes, are shown. (a,b) Co-culture density at $10^{5}$ cells; (a) granulosa focal plane (granulosa cell clumps are indicated by arrows) and (b) theca focal plane (theca cell clumps are indicated by arrowheads). (c,d) Co-culture density at $3 \times 10^{5}$ cells; (c) granulosa focal plane (granulosa cell clumps are indicated by arrows) and (d) theca focal plane (theca cell clumps are indicated by arrowheads). Scale bars represent $100 \mu \mathrm{m}$.

the initial plating number. The number of granulosa cells recovered from co-cultures was significantly higher than that from mono-cultures $(P<0.001)$. No significant difference in theca cell survival was observed between mono-cultures and co-cultures (Fig. 3a). Treatment of the co-culture with either combination of treatment hormones (treatment $\mathrm{A}$ or treatment $\mathrm{B}$ ) under the same experimental conditions resulted in an increase in the number of viable theca cells in comparison with basal conditions (treatment $A: P<0.01$; treatment $B$ : $P<0.001)$. The treatments did not affect the number of viable granulosa cells in co-culture compared with the number observed under basal conditions (Fig. 3b). Theca cells in co-culture at $3 \times 10^{5}$ cell plating density survived better compared with those at the lower cell density in all culture conditions (basal conditions: $P<0.001$; treatment A: $P<0.01$; treatment B: $P<0.05$ ).
The increased number of viable theca cells at $3 \times$ $10^{5}$ cell plating density was related to the higher number of cells in culture as no significant difference in the number of cells was observed when cultures were performed in basal conditions, or with either combination of treatment hormones (Fig. 3c). This plating density effect was not observed for granulosa cells. The number of viable granulosa cells in co-culture at $3 \times 10^{5}$ cells plating density was the same at $10^{5}$ cells and was unaffected by treatments (Fig. 3b,c).

\section{Hormone production under basal conditions}

Mono-culture and co-culture at a plating density of $10^{5}$ cells. Androstenedione concentrations were higher in co-culture than in mono-culture $(P<0.05)$ and varied significantly with time $(P<0.001$; Fig. 4a). 


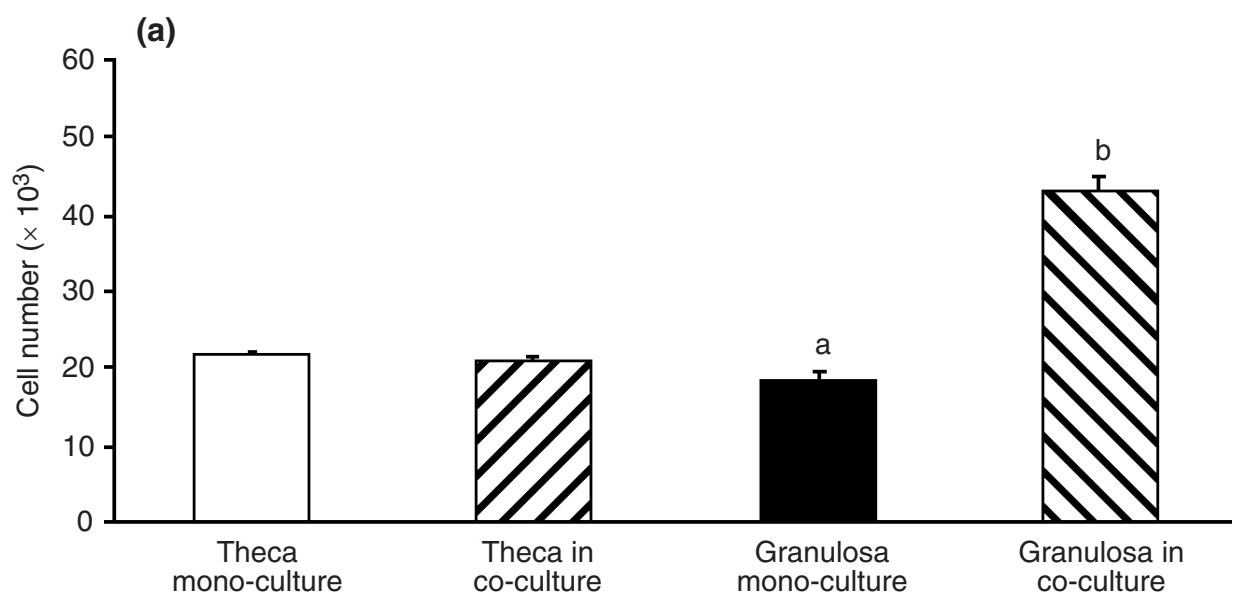

(b)

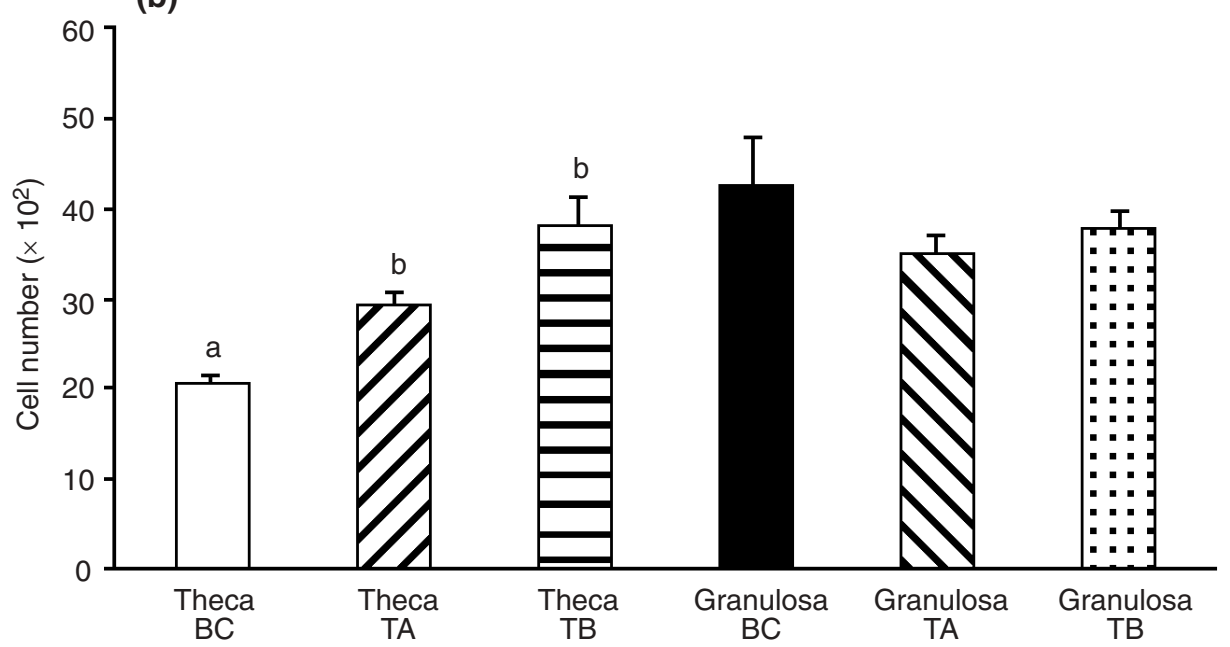

(c)

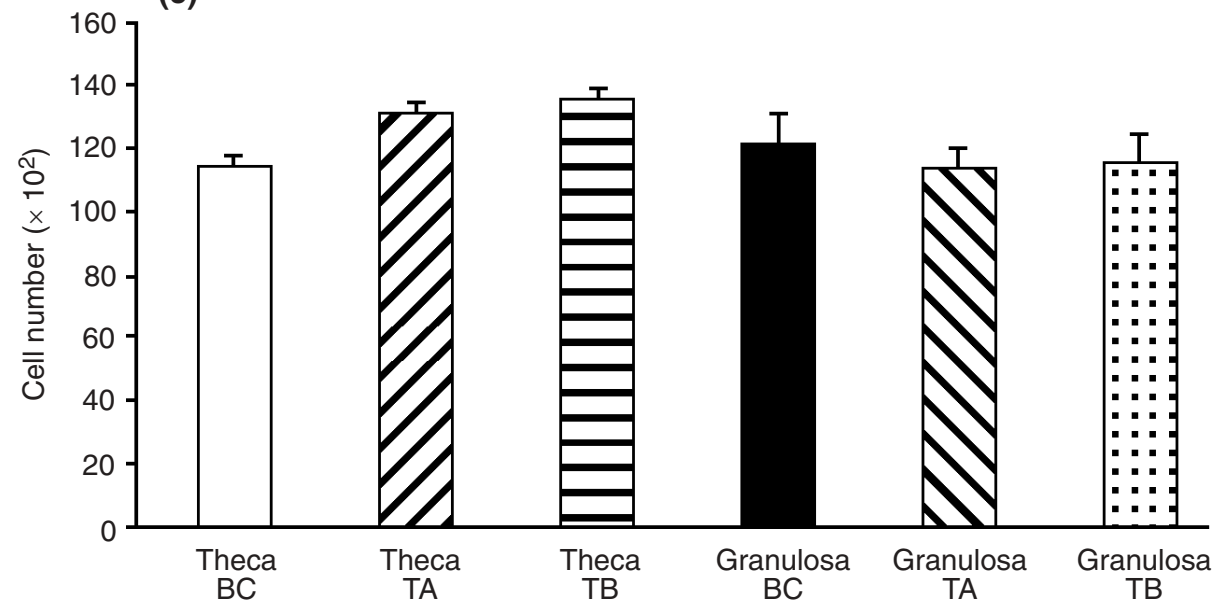

Fig. 3. The number of viable bovine theca and granulosa cells at the end of the culture period. The number of cells was estimated by methyltriazole tetrazolium conversion by metabolically active cells. Values are means \pm SEM ( $n=6$ independent cultures). Statistical comparisons of the means were performed by one-way ANOVA followed by Tukey-Kramer post hoc test $\left.{ }^{\mathrm{a}, \mathrm{b}} P<0.05\right)$. (a) Cell survival in mono-culture and co-culture in basal conditions at plating density of $10^{5}$ cells; (b) cell survival in co-culture at plating density of $10^{5}$ cells under basal conditions (BC), treatment $\mathrm{A}$ (TA) and treatment $B(\mathrm{~TB})$; and (c) cell survival in co-culture at plating density of $3 \times 10^{5}$ cells under basal conditions $(\mathrm{BC})$, treatment $\mathrm{A}(\mathrm{TA})$ and treatment $\mathrm{B}(\mathrm{TB})$. 
(a)
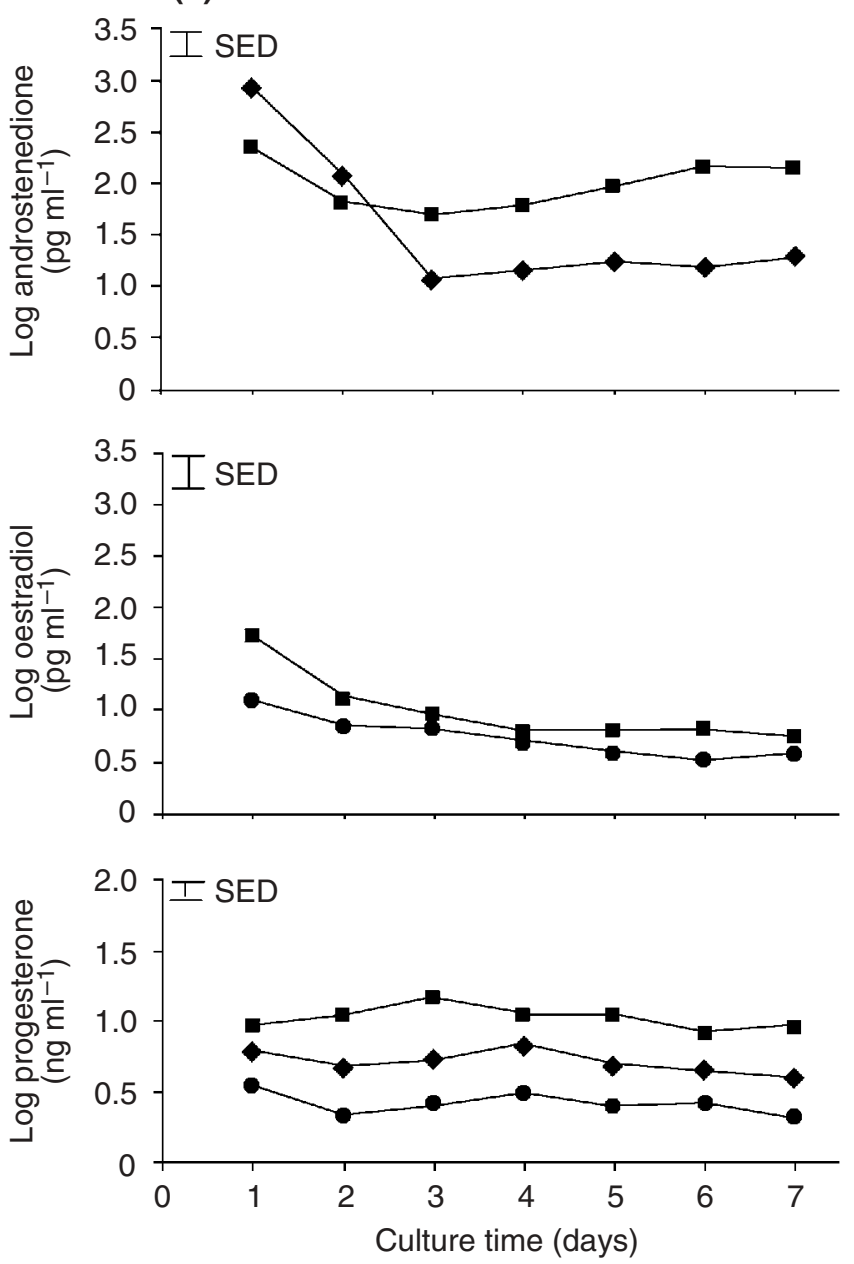

(b)
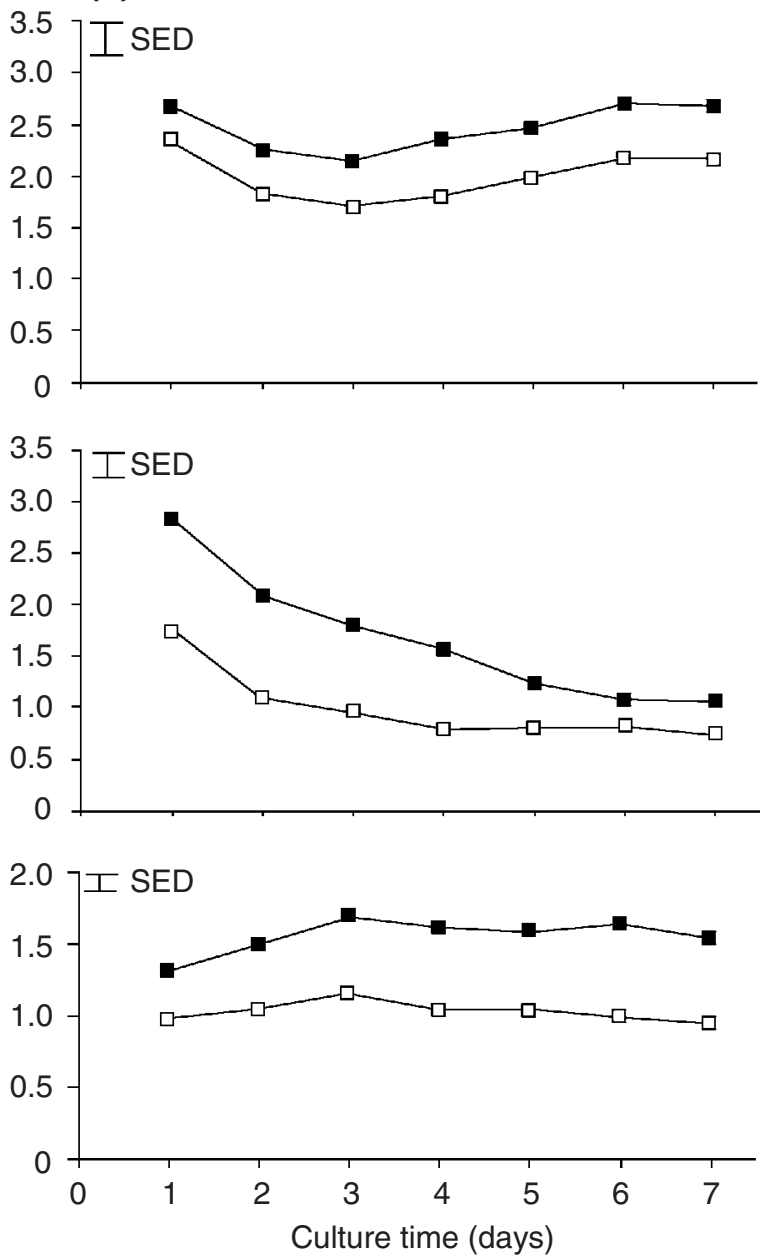

Fig. 4. Time course of secretion of androstenedione, oestradiol and progesterone under basal conditions (10 $\left.\mathrm{ng}^{\mathrm{insulin}} \mathrm{ml}^{-1}\right)$ at cell plating density of either (a) $10^{5}$ or (b) $3 \times 10^{5}$ bovine cells. (a) Secretion profiles of mono-cultures and co-cultures ( $\$$ : theca

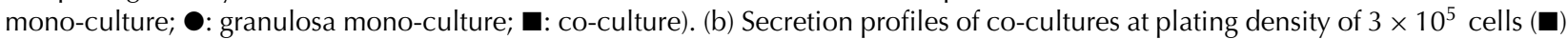
compared with those at plating density of $10^{5}$ cells $(\square)$. Values are the means of eight separate cultures in triplicate. Data were log transformed to remove heterogeneity of variance before repeated measures of ANOVA. The pooled variance was used to calculate the SED between means. Differences between means greater than the SED are significant $(P<0.05)$.

Androstenedione concentrations declined markedly in theca mono-culture, whereas a more constant hormone production was observed in co-culture.

Oestradiol concentrations were low and not significantly different between mono-culture and co-culture (Fig. 4a). Co-cultured cells produced more progesterone compared with the respective mono-cultured cells $(P<0.001$; Fig. 4a), but no difference between coculture and mono-culture was observed in the pattern of secretion over time.

Co-culture at a plating density of $3 \times 10^{5}$ cells. Cocultures with $3 \times 10^{5}$ cells under basal conditions produced threefold more androstenedione compared with co-cultures at the lower cell density $(P<0.01)$. However, no significant difference was observed in androstenedione production with time in culture (Fig. 4b).
Oestradiol concentrations under basal conditions were increased significantly $(P<0.001)$ compared with cocultures at the lower cell plating density. In addition, a significantly distinct reduction in production was observed during the period of culture ( $P<0.001$; Fig. $4 \mathrm{~b})$. Co-cultures with $3 \times 10^{5}$ cells under basal conditions produced threefold more progesterone compared with co-cultures at the lower cell plating density $(P<0.001)$. There was also a significantly different secretion pattern $(P<0.05$; Fig. 4b).

\section{Effect of LR3 IGF-I, FSH and LH on hormone production on co-cultures}

Androstenedione. Treatment A increased the concentration of androstenedione in co-cultures when cells were plated at a density of $10^{5}$ cells (Fig. 5a). 
(a)
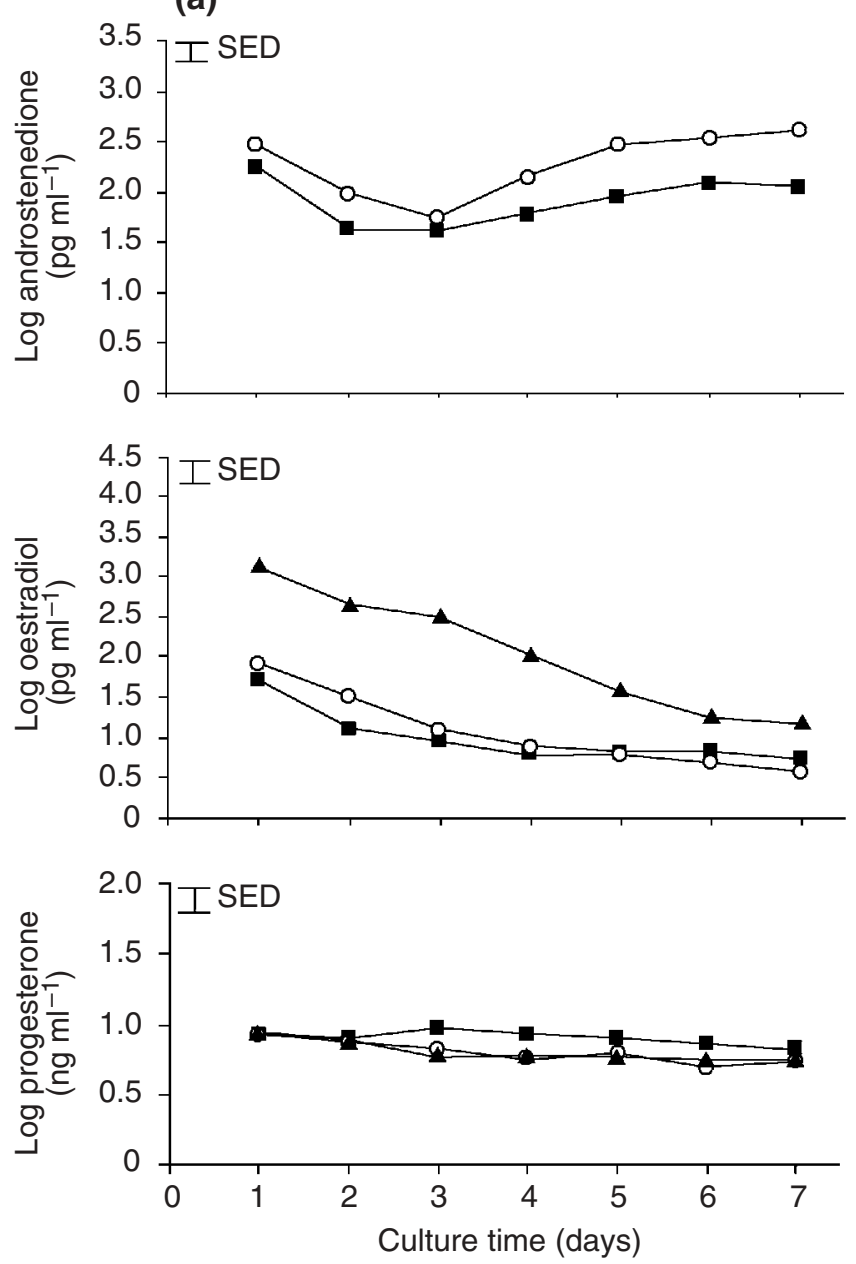

(b)
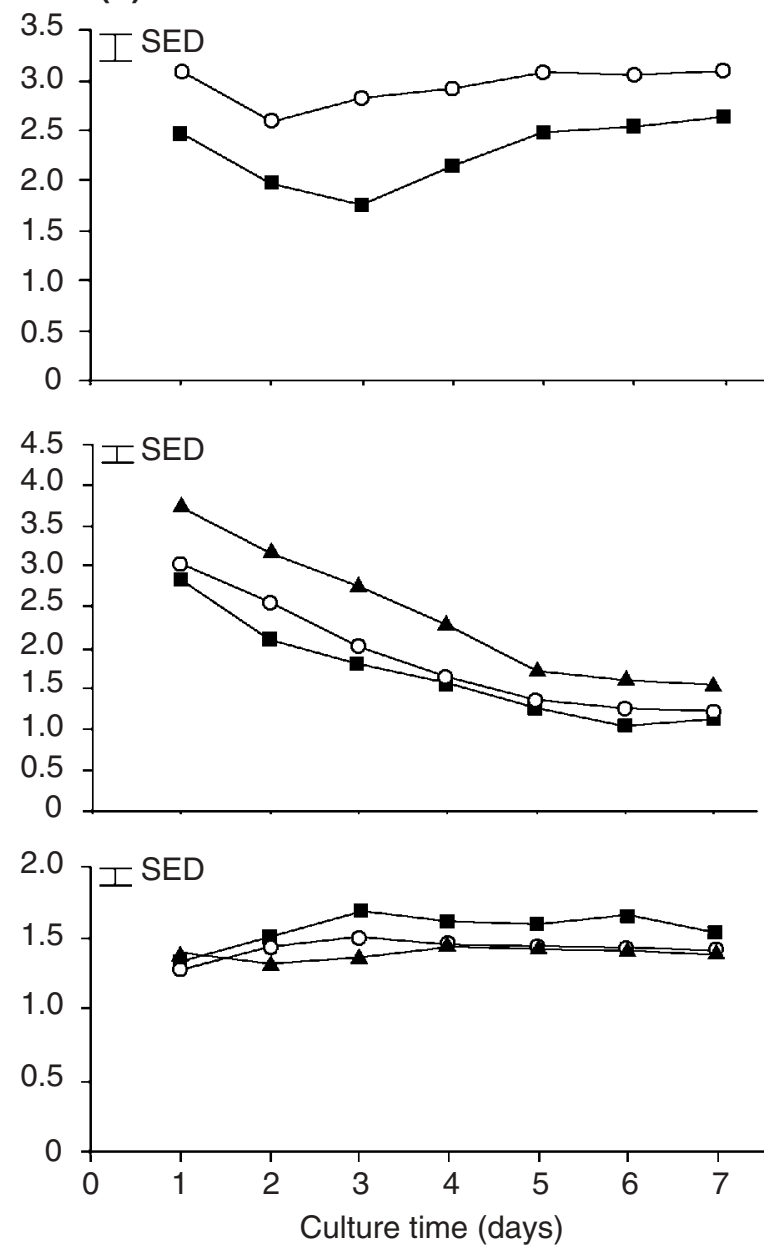

Fig. 5. Time course of secretion of androstenedione, oestradiol and progesterone by co-cultures treated with treatment $A$ and treatment $B$ at cell plating density of either (a) $10^{5}$ or (b) $3 \times 10^{5}$ bovine cells. (a) Secretion profiles of co-cultures at plating density of $10^{5}$ cells treated with treatment $\mathrm{A}(\mathrm{O})$ and treatment $\mathrm{B}(\mathbf{\Lambda})$ compared with basal conditions $(\boldsymbol{\square})$. (b) Secretion profiles of co-cultures at plating density of $3 \times 10^{5}$ cells treated with treatment $A(O)$ and treatment $B(\boldsymbol{\Lambda})$ compared with basal conditions $(\boldsymbol{\square})$. Values are the means of four separate cultures in triplicate. Data were log transformed to remove heterogeneity of variance before repeated measures ANOVA. The pooled variance was used to calculate the SED between means. Differences between means greater than the SED are significant $(P<0.05)$.

Androstenedione concentrations were significantly higher $(P<0.05)$ compared with those measured under basal conditions, but hormone production over time did not change significantly. The increase in secretion on the last day of culture was almost twofold more than that seen under basal conditions (Table 1). Under treatment A, co-cultures with $3 \times 10^{5}$ cells secreted significantly $(P<0.001)$ more androstenedione compared with that produced by cells under basal conditions at the same cell plating density. The secretion profile changed significantly during culture $(P<0.05)$, as shown (Fig. $5 b)$. The treatment resulted in an almost threefold increase in androstenedione concentrations, as measured on day 7 of culture (Table 1 ). Co-cultures with $3 \times 10^{5}$ cells produced significantly more androstenedione compared with co-cultures at the lower cell plating density in the same experimental conditions $(P<0.005)$. However, no significant difference was observed in production over time.

Oestradiol. Treatment A, at a plating density of $10^{5}$ cells, produced no significant difference in oestradiol concentrations when compared with co-cultures under basal conditions (Fig. 5a). Treatment B significantly increased oestradiol concentrations $(P<0.001)$. The pattern of secretion over the time of culture was significantly different $(P<0.001)$ and the increased hormone production was maintained throughout the culture period (Fig. 5a and Table 1). Co-cultures with $3 \times 10^{5}$ cells showed a significant increase in oestradiol concentrations in response to treatment $\mathrm{A}$ when compared with those under basal conditions $(P<0.005$; Fig. 5b). 
Table 1. Content of androstenedione (log pg per $2 \times 10^{4}$ cells per $24 \mathrm{~h}$ ), oestradiol (log pg per $2 \times 10^{4}$ cells per 24 h) and progesterone (log ng per $2 \times 10^{4}$ cells per $24 \mathrm{~h}$ ) in bovine co-cultures at day 7

\begin{tabular}{|c|c|c|c|c|c|c|}
\hline \multirow[b]{2}{*}{ Culture conditions } & \multicolumn{3}{|c|}{$10^{5}$ cells } & \multicolumn{3}{|c|}{$3 \times 10^{5}$ cells } \\
\hline & Androstenedione & Oestradiol & Progesterone & Androstenedione & Oestradiol & Progesterone \\
\hline Basal & $2.10^{\mathrm{a}}(125.9)$ & $0.40^{\mathrm{a}}(2.5)$ & $0.40^{\mathrm{a}}(2.5)$ & $1.87^{\mathrm{a}}(74.1)$ & $0.30^{\mathrm{a}}(1.99)$ & $0.60^{\mathrm{a}}(4.0)$ \\
\hline LR3 IGF-I, FSH, LH & $2.45^{\mathrm{b}}(281.8)$ & $0.24^{\mathrm{a}}(1.7)$ & $0.24^{\mathrm{a}}(1.7)$ & $2.31^{\mathrm{b}}(204.2)$ & $0.44^{\mathrm{a}}(2.75)$ & $0.30^{b}(2.0)$ \\
\hline LR3 IGF-I, FSH, androstenedione & & $0.89^{b}(7.8)$ & $0.20^{\mathrm{a}}(1.6)$ & & $0.76^{b}(5.75)$ & $0.33^{b}(2.1)$ \\
\hline
\end{tabular}

Results are log of median steroid concentrations (absolute concentrations are given in parentheses).

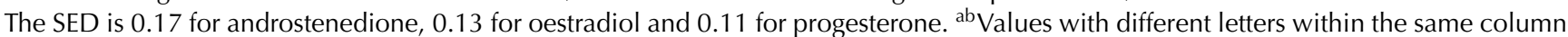
are significantly different $(P<0.05)$.

IGF-I: insulin-like growth factor I.

However, the secretion profiles over time were not significantly different. Treatment B markedly increased the concentration of oestradiol $(P<0.001)$ and a different pattern of secretion was observed over time $(P<0.001$; Fig. $5 b$ and Table 1). Both combinations of treatment hormones increased oestradiol production compared with co-cultures at the lower cell density under the same experimental conditions $(P<0.001)$ and a significantly distinct profile of production was observed during culture $(P<0.001)$.

Progesterone. Neither treatment affected progesterone concentrations when compared with cells cultured under basal conditions (Fig. 5 and Table 1). However, when progesterone concentrations were measured on the last day of culture and corrected for the number of viable cells present at that time, treatments had resulted in a significant decrease in secretion $(P<0.005$; Table 1). Progesterone concentrations at the higher plating density, under either combination of treatment hormones, were significantly higher $(P<0.01)$ than those at the lower plating density under the same treatments and a significant difference in secretion over time was observed ( $P<0.005$; Fig. 5a).

\section{Discussion}

The present study is to our knowledge the first to describe a serum-free co-culture system for granulosa and theca cells supported on a membrane coated with an ECM component. In this system, cells cultured under basal conditions $\left(10 \mathrm{ng}\right.$ insulin $\mathrm{ml}^{-1}$ ) retained the ability to secrete steroid hormones for at least 7 days. In addition, steroidogenesis was influenced by hormone treatment and plating density. When compared with monocultures, co-cultured cells showed evidence of paracrine communication through enhanced steroidogenesis and cell survival.

The serum-free medium and the combination of treatment hormones and concentrations used in the present study were based on those used in previous serum-free culture systems, developed for bovine and ovine granulosa cells (Campbell et al., 1996; Gutierrez et al., 1997) and for ovine and pig theca cells (Campbell et al., 1998; Picton et al., 1999; Shores et al., 2000). Cell culture inserts coated with laminin were chosen to support cells in culture. Laminin is one of the most abundant ECM components within the basal lamina (Zhao and Luck, 1995; Colognato and Yurchenco, 2000; Rodgers et al., 2000) and is capable of preventing apoptosis and maintaining cell morphology to the same extent as intact ECM (Aharoni et al., 1997). In particular, it has been reported that laminin improves survival of rat and sheep granulosa cells (Aharoni et al., 1997; Huet et al., 2001; Le Bellego et al., 2002). However, rat and sheep granulosa cells cultured in serum-free conditions on a laminin substratum did not retain the gross morphology of cell clumps, described as the 'follicular phenotype' by several authors (Campbell et al., 1996; Gutierrez et al., 1997). The bovine cells in the system used in the present study rapidly attained the clumped morphology after being plated as a dispersion, which mimics the ovarian follicle environment in which only cells in contact with the ECM components of the basement membrane assume a 'flattened' morphology; the subsequent layers of cells, faraway from the basement membrane, assume a 'more rounded morphology' (Irving-Rodgers and Rodgers, 2000). Cells in the system used in the present study also retained endocrine features associated with the follicular phenotype and survived at rates comparable with those of cells in serum-free monoculture. ECM-induced granulosa cell differentiation is modulated by gonadotrophins and growth factors (Aharoni et al., 1997; Huet et al., 2001), so it is possible that a higher degree of differentiation is obtained when cultures are performed in the presence of these regulators. For this reason, the culture system used in the present study was characterized first under basal conditions (in the presence of $10 \mathrm{ng}$ insulin $\mathrm{ml}^{-1}$ ), and subsequently in the presence of physiological concentrations of gonadotrophins and growth factors.

Under basal conditions, comparison between monocultures and co-cultures was performed at a plating 
density of $10^{5}$ cells. This plating density was initially chosen in accordance with the optimal cell density reported in previous serum-free culture studies carried on an equivalent surface area (Gutierrez et al., 1997; Campbell et al., 1998; Shores et al., 2000). Granulosa cells showed a twofold increase in viability when cocultured with theca cells. This finding is consistent with reports that bovine theca cells secrete a range of factors (for example, TGF- $\alpha, \mathrm{KGF}$ and HGF) that can sustain granulosa cells in culture (Skinner and Coffey, 1988; Parrott et al., 1994). A similar positive effect of theca cells on granulosa cell viability has been reported by different authors in co-culture experiments in which cells were cultured in partial serum-free conditions (first cultured with serum and then in serum-free medium; Bendell et al., 1988; Tajima et al., 2002).

Co-operation between granulosa and theca cells was also apparent at the hormone level. The concentrations of androstenedione were higher in co-cultures compared with mono-cultures, indicating a positive effect of granulosa cells on thecal steroidogenesis. A similar feature has been reported in studies of bovine theca and follicle wall preparations cultured in serum-free conditions (Fortune, 1986) and by bovine theca and granulosa cells cocultured in partial serum-free conditions (Wrathall and Knight, 1995; Yada et al., 1999). The mechanisms responsible for this effect are still unknown, but it has been suggested that oestradiol and inhibin secreted by granulosa cells can induce an increased secretion of androstenedione by theca cells (Fortune, 1986; Roberts and Skinner, 1990; Wrathall and Knight, 1995; Webb et al., 1999). This mechanism may be applicable to the system used in the present study as granulosa cells cultured in serum-free medium supplemented with androstenedione are capable of producing oestradiol and inhibin (Campbell et al., 1996; Glister et al., 2001). We did not observe any oestradiol accumulation when cells were cultured under basal conditions because exogenous androstenedione was not included in the medium and was therefore unavailable as an aromatase substrate. Although androstenedione concentrations were higher in co-cultures, oestradiol concentrations in co-cultures were not different from those measured in monocultures. This apparent discrepancy can be explained on the basis that androstenedione concentrations in co-cultures remained at concentrations to which the granulosa aromatase cytochrome P450 (P450 aromatase) is relatively insensitive; androstenedione affinity for $\mathrm{P} 450$ aromatase in the ovary is in the nanomolar range (Conley, 2001) and androstenedione concentrations in co-cultures are sub-nanomolar.

Progesterone concentrations in co-cultures were significantly higher compared with those in monocultures. The increased progesterone production in cocultures was a synergistic effect of the presence of the two types of cell, rather than an additive one. Despite the higher concentrations of progesterone, as compared with those of androstenedione and oestradiol, several features indicate that cells in the present coculture system did not undergo luteinization. First, progesterone secretion by luteinizing cells typically increases extremely rapidly over the duration of culture (Luck et al., 1990); concentrations in the cultures used in the present study remained constant. Second, oestradiol and androstenedione synthesis continued throughout the culture period and remained responsive to low doses of FSH, LH and the IGF-I analogue, LR3-IGF-I. Secretion of oestradiol by luteinizing cells declines rapidly to minimal or undetectable levels within the first few days of culture (Luck et al., 1990). The low oestradiol concentrations observed in the cultures of the present study may be the result of culture on a laminin-coated membrane. It has been shown that laminin suppresses oestradiol, but increases progesterone secretion in granulosa cell culture in serum-free conditions (Huet et al., 2001). Nevertheless, addition of exogenous androstenedione significantly stimulated oestradiol production during all periods of culture, demonstrating that granulosa cells maintained their P450 aromatase activity.

Treatment of co-cultures with either combination of treatment hormones produced not only a positive effect on hormone secretion, but also significantly affected theca cell survival. An almost twofold increase in the number of theca cells was measured at the end of culture compared with cells cultured under basal conditions. In contrast, no effect was observed on granulosa cell viability. These results indicate an anti-apoptotic effect of treatments on theca cells. The proliferative effect of LR3-IGF-I on granulosa and theca cells has been shown in previous experiments conducted under serum-free conditions. In particular, it has been reported that LR3IGF-I, at the same concentration used in our study, stimulated proliferation of ovine theca cells in the presence of low doses of LH (Campbell et al., 1998), but not of bovine granulosa cells in the presence of low doses of FSH (Gutierrez et al., 1997). The positive effect exerted by treatments on theca cell viability in co-culture was not observed when cells were plated at higher density; theca cells cultured under basal conditions survived better at the higher plating density, with no further increase in number of cells even in the presence of treatments. Previous studies demonstrated that plating density had a detrimental effect on thecal hormone secretion (Campbell et al., 1998; Shores et al., 2000). In the system used in the present study, the culture surface area is approximately the same as that of a well in the conventional 96-well plates used in previous culture studies. It was proposed that the absence of any detrimental effect of increasing the number of cells may be the result of having the cell culture inserts fitted in a 24-well plate and incubated in $1 \mathrm{ml}$ of medium (four times larger volume than in previous studies; Campbell et al., 1998; Shores et al., 2000), thereby avoiding the negative effects of metabolic by-product accumulation. 
Co-culture at the higher plating density under basal conditions produced significantly more androstenedione, oestradiol and progesterone compared with that at the lower plating density. Furthermore, secretion of androstenedione and oestradiol was stimulated by treatment with both combinations of treatment hormones. The addition of exogenous androstenedione increased oestradiol secretion indicating an active $\mathrm{P} 450$ aromatase in these culture conditions. Interestingly, progesterone concentrations, measured on the last day of culture and corrected for the number of viable cells in culture, were decreased compared with production by cells in basal conditions. These results indicate that cells are more able to retain their follicular phenotype when cultured at a higher plating density. Thus, it was concluded that plating density has a marked effect in this co-culture system, increasing both cell viability and hormone production.

A previous in vitro model described granulosa and theca cell interactions in a co-culture system on a collagen membrane (Kotsuji et al., 1990; Yada et al., 1999). In that system, serum was used for the initial $48 \mathrm{~h}$ of culture to allow cell attachment and then superphysiological doses of insulin were used for the rest of the culture period (Kotsuji et al., 1990; Yada et al., 1999; Tajima et al., 2002). These differences in design between the two systems preclude a direct comparison of results, although the earlier studies also found that theca cells maintained granulosa viability by preventing apoptosis (Tajima et al., 2002) and that granulosa cells increased androstenedione production by theca cells (Yada et al., 1999).

In conclusion, a serum-free co-culture system has been developed for bovine granulosa and theca cells in which paracrine communication across a laminincoated membrane promotes steroidogenesis and cell survival. Co-cultured cells respond to physiological concentrations of gonadotrophins and an IGF-I analogue and maintain a follicular phenotype, especially when plated at a higher density. Taken together, these characteristics indicate that the co-culture system provides a model for the study of cell-cell and cell-ECM interactions and may be useful for investigating tissue remodelling during follicle growth.

The authors thank P. Michas, M. Mierzwinska and C. Patriarchea for their contributions to the development of the co-culture system, J. Corbett for collecting bovine ovaries, J. Craigon for advice on statistical analysis, and M. Mitchell for the preparation of iodinated hormones. This research was supported by BBSRC (42/S13899).

\section{References}

Adams JC and Watt FM (1993) Regulation of development and differentiation by the extracellular matrix Development 117 1183-1198

Aharoni D, Meiri I, Atzmon R, Vlodavsky I and Amsterdam A (1997) Differential effect of components of the extracellular matrix on differentiation and apoptosis Current Biology 7 43-51
Bendell JJ, Lobb DK, Chuma A, Gysler M and Dorrington JH (1988) Bovine thecal cells secrete factor(s) that promote granulosa cell proliferation Biology of Reproduction 38 790-797

Campbell BK, Scaramuzzi RJ and Webb R (1996) Induction and maintenance of oestradiol and immunoreactive inhibin production with FSH by ovine granulosa cells cultured in serum-free media Journal of Reproduction and Fertility 106 7-16

Campbell BK, Baird DT and Webb R (1998) Effects of dose of LH on androgen production and luteinization of ovine theca cells cultured in a serum-free system Journal of Reproduction and Fertility $\mathbf{1 1 2}$ 69-77

Colognato H and Yurchenco PD (2000) Form and function: the laminin family of heterotrimers Developmental Dynamics 218 213-234

Conley A and Hinshelwood M (2001) Mammalian aromatases Reproduction 121 685-695

Fortune JE (1986) Bovine theca and granulosa cells interact to promote androgen production Biology of Reproduction 35 292-299

Glister C, Tannetta DS, Groome NP and Knight PG (2001) Interactions between follicle-stimulating hormone and growth factors in modulating secretion of steroids and inhibin-related peptides by non-luteinized bovine granulosa cells Biology of Reproduction 65 1020-1028

Gong JG, McBride D, Bramley TA and Webb R (1994) Effects of recombinant bovine somatotrophin, insulin-like growth factor-I and insulin on bovine granulosa cell steroidogenesis in vitro. Journal of Endocrinology $\mathbf{1 4 3}$ 157-164

Gore-Langton R and Armstrong DG (1994) Follicular steroidogenesis and its control. In The Physiology of Reproduction pp 571-627 Eds E Knobil and J Neill, 4th Edn. New York: Raven Press Ltd

Gutierrez CG, Campbell BK and Webb R (1997) Development of a longterm bovine granulosa cell culture system: induction and maintenance of oestradiol production, response to follicle-stimulating hormone, and morphological characteristics Biology of Reproduction $\mathbf{5 6}$ 608-616

Huet C, Pisselet C, Mandon-Pepin B, Monget P and Monniaux D (2001) Extracellular matrix regulates ovine granulosa cell survival, proliferation and steroidogenesis: relationships between cell shape and function Journal of Endocrinology 169 347-360

Ireland JJ, Murphee RL and Coulson PB (1980) Accuracy of predicting stages of bovine estrous cycle by gross appearance of the corpus luteum Journal of Diary Science 63 155-160

Irving-Rodgers HF and Rodgers RJ (2000) Ultrastructure of the basal lamina of bovine ovarian follicle and its relation to the membrane granulosa Journal of Reproduction and Fertility 118 221-228

Knight PG and Glister C (2001) Potential local regulatory functions of inhibins, activins and follistatin in the ovary Reproduction 121503 512

Kotsuji F, Kamitani N, Goto K and Tominaga T (1990) Bovine theca and granulosa cell interactions modulate their growth, morphology and function Biology of Reproduction 43 726-732

Le Bellego F, Pisselet C, Huet C, Monget P and Monniaux D (2002) Laminin-alpha 6 beta 1 integrin interaction enhances survival and proliferation and modulates steroidogenesis of ovine granulosa cells Journal of Endocrinology 172 45-59

Luck MR (1994) The gonadal extracellular matrix Oxford Reviews of Reproductive Biology $\mathbf{1 6} 33-85$

Luck MR, Rodgers RJ and Findlay JK (1990) Secretion and gene expression of inhibin, oxytocin and steroid hormones during the in vitro differentiation of bovine granulosa cells Reproduction, Fertility and Development 2 $11-25$

Metcalf MG (1982) Estimation of viability of bovine granulosa cells Journal of Reproduction and Fertility $\mathbf{6 5}$ 425-429

Monniaux D, Monget P, Besnard N, Huet C and Pisselet C (1997) Growth factors and antral follicular development in domestic ruminants Theriogenology 47 3-12

Mosmann T (1983) Rapid colorimetric assay for cellular growth and survival: application to proliferation and cytotoxicity assays Journal of Immunological Methods 65 55-63

Nilsson E and Skinner MK (2001) Cellular interactions that control primordial follicle development and folliculogenesis Journal of Society for Gynecological Investigation 8 S17-S20 
Parrott JA, Vigne JL, Chu BZ and Skinner MK (1994) Mesenchymalepithelial interactions in the ovarian follicle involve keratinocyte and hepatocyte growth factor production by thecal cells and their action on granulosa cells Endocrinology 135 569-575

Picton HM, Campbell BK and Hunter MG (1999) Maintenance of oestradiol production and expression of cytochrome P450 aromatase enzyme mRNA in long-term serum-free cultures of pig granulosa cells Journal of Reproduction and Fertility 115 67-77

Roberts AJ and Skinner MK (1990) Estrogen regulation of thecal cell steroidogenesis and differentiation: thecal cell-granulosa cell interactions Endocrinology 127 2918-2929

Rodgers RJ and Irving Rodgers HF (2002) Extracellular matrix of the bovine ovarian membrana granulosa Molecular and Cellular Endocrinology 191 $57-64$

Rodgers RJ, Irving-Rodgers HF and van Wezel IL (2000) Extracellular matrix in ovarian follicles Molecular and Cellular Endocrinology 163 73-79

Shores EM, Picton HM and Hunter MG (2000) Differential regulation of pig theca cell steroidogenesis by $\mathrm{LH}$, insulin-like growth factor I and granulosa cells in serum-free culture Journal of Reproduction and Fertility 118 211-219

Skinner MK and Coffey RJ, Jr (1988) Regulation of ovarian cell growth through the local production of transforming growth factor-alpha by theca cells Endocrinology 123 2632-2638

Streuli C (1999) Extracellular matrix remodelling and cellular differentiation Current Opinion in Cell Biology 11 634-640

Tajima K, Orisaka M, Hosokawa K, Amsterdam A and Kotsuji F (2002) Effects of ovarian theca cells on apoptosis and proliferation of granulosa cells: changes during bovine follicular maturation Biology of Reproduction $\mathbf{6 6}$ 1635-1639
Webb R, Campbell BK, Garverick HA, Gong JG, Gutierrez CG and Armstrong DG (1999) Molecular mechanisms regulating follicular recruitment and selection Journal of Reproduction and Fertility Supplement $\mathbf{5 4}$ 33-48

Wrathall JH and Knight PG (1995) Effects of inhibin-related peptides and oestradiol on androstenedione and progesterone secretion by bovine theca cells in vitro. Journal of Endocrinology 145491 500

Yada H, Hosokawa K, Tajima K, Hasegawa Y and Kotsuji F (1999) Role of ovarian theca and granulosa cell interaction in hormone production and cell growth during the bovine follicular maturation process Biology of Reproduction 61 1480-1486

Yurchenco PD, Tsilibary EC, Charonis AS and Furthmayr H (1985) Laminin polymerization in vitro: evidence for a two-step assembly with domain specificity Journal of Biological Chemistry 2607636 7644

Yurchenco PD, Cheng YS and Colognato H (1992) Laminin forms an independent network in basement membranes Journal of Cell Biology 117 1119-1133

Zhao Y and Luck MR (1995) Gene expression and protein distribution of collagen, fibronectin and laminin in bovine follicles and corpora lutea Journal of Reproduction and Fertility 104 115-123

Received 18 February 2003.

First decision 15 April 2003.

Revised manuscript received 15 May 2003.

Accepted 9 June 2003. 